\title{
KAJIAN ASPEK FOTOGRAFIS DALAM TEHNIK OLAH DIGITAL POSTER FILM “ SANG PEMIMPI ”
}

\author{
Noor Latif CM \\ Jurusan Desain Komunikasi Visual, Fakultas Komunikasi dan Multimedia, Bina Nusantara University \\ Jl. K.H. Syahdan No. 9, Kemanggisan, Jakarta Barat 11480 \\ lateevhaq@gmail.com
}

\begin{abstract}
As the advancement of digital imaging technology, this urges internal actors to be more accurate and explorative in producing visual communication work with photography element and digital touching process. Digital process ability with no photographical ability will produce raw and anomaly visual work of art. Besides, audience is smarter and more appreciative towards quality of visual appearance in several modern communication media. Film poster of Sang Pemimpi is a case reflection of general digital in visual communication work that has gap among communication product content according to the brand of the film. Photography element composition is melted with bondless pile among the objects. Logical photography as bonding bridge of visual logic is weak in execution; where we could see it has less digital process commercial market need with the supporting resources.
\end{abstract}

Keywords: digital process, photography, film poster, Sang Pemimpi

\begin{abstract}
ABSTRAK
Semakin pesatnya perkembangan tehnologi pencitraan digital, hal itu menuntut para pelaku di dalamnya untuk lebih cermat dan eksploratif dalam menghasilkan karya komunikasi visual dengan elemen fotografi dan sentuhan olah digital. Kemampuan olah digital yang tidak diimbangi dengan kemampuan sudut pandang fotografis akan menjadikan karya seni visual yang mentah dan janggal. Di sisi lain audien semakin cerdas dan apresiatif terhadap kualitas tampilan visual yang hadir di berbagai media komunikasi modern. Poster film "Sang Pemimpi" adalah refleksi kasus olah digital secara umum dalam karya komunikasi visual yang mengalami kesenjangan antara konten produk komunikasi yang di emban dengan media visual pembawanya. Kurangnya penggarapan detail dari sisi teknis fotografis menjadi kendala poster film tersebut dapat menampilkan tampilan visual yang sesuai dengan nama besar film tersebut. Komposisi elemen fotografi bersatu dalam tumpukan tanpa ikatan yang kuat antar obyeknya. Logika fotografis sebagai jembatan penghubung nilai-nilai logika visual lemah dalam penggarapan eksekusinya. Di sini bisa kita lihat belum tercukupinya kebutuhan pasar komersial olah digital dengan kekuatan sumber daya pendukungnya.
\end{abstract}

Kata kunci: olah digital, fotografi, poster film, sang pemimpi 


\section{PENDAHULUAN}

Olah digital adalah elemen yang sangat penting dalam perkembangan fotografi digital dalam kancah seni visual modern. Hampir dipastikan tidak ada karya fotografi manapun yang tidak tersentuh oleh proses olah digital. Proses olah digital dalam fotografi sudah mulai berjalan saat dimana Fotografer belum melakukan aktifitas pemotretan, karena kemampuan prosesor kamera digital yang memungkinkan kita melakukan penyetingan parameter kwalitas gambar secara otomatis maupun manual. Dewasa ini olah digital berkembang cukup pesat karena percepatan produksi tehnologi untuk mendukung kemampuan pengolahan gambar secara digital.

Pesatnya perkembangan tehnologi perangkat pencitraan digital baik keras maupun lunak, memberikan imbas yang sangat kuat kepada para pelaku seni visual digital untuk mencapai kesempurnaan dalam menuangkan gagasan visual tanpa batas. Kendala tehnis bukan lagi menjadi pokok bahasan yang signifikan, melainkan lebih kepada harapan munculnya kontes gagasan kreatif yang orisinal dengan pendekatan tehnis tanpa cela. Etalase-etalase seni visual digital dari kelas marginal yang hanya mengedepankan teknis olah digital paritas sampai kelas eksklusif minoritas pengusung gagasan, sangat mudah diakses masyarakat awam lewat aneka media komunikasi modern. Keterlibatan masyarakat awam secara intens dalam apresiasi karya visual digital, mengarah pada terbentuknya komunitas awam secara luas yang sudah tidak lagi gagap visual dalam mencerna kerumitan tampilan karya olah digital. Bahkan dengan kemudahan yang ada memunculkan pelakupelaku baru dalam jumlah banyak yang dapat menguasi perangkat lunak pengolah gambar secara digital, sayangnya banyak dari mereka yang tidak diimbangi dengan kemampuan artisitik dan tehnis secara benar. Yang lebih parahnya lagi serapan pasar komersial terhadap pelaku instan untuk memoles konten komunikasi yang diusungnya cukup besar, terbukti dengan bertebarannya produk komunikasi visual kelas atas yang lemah dari sisi tehnis dan artistik.

Kemampuan media komunikasi visual yang menggunakan elemen pendukung karya fotografi dengan polesan olah digital harus mampu hadir berbanding lurus dengan kwalitas apresiasi audiennya. Kegagalan menyuguhkan kesempurnaan tampilan visual akan penjadi salah satu elemen penghambat dalam penyampaian pesan yang sesuai dengan strategi kreatif yang diembannya.

Banyak kasus media komunikasi visual dimasyarakat yang dapat kita cermati sebagai bahan kajian tehnis olah digital ditinjau dari aspek fotografis, salah satunya poster film Sang Pemimpi yang akan menjadi topik kajian. Sang Pemimpi adalah sebuah film Indonesia tahun 2009 yang diadaptasi dari tetralogi novel Laskar Pelangi kedua karya novelis Andrea hirata, yang digarap apik Riri reza sebagai sutradara dan Mira lesmana sebagai produser. Nama besar mereka layak menjadi jaminan kwalitas film tersebut baik dari aspek pasar hiburan maupun gagasan kreatif sinematografi. Bahkan Andrea hirata sendiri menyatakan kalau film Sang Pemimpi tiga kali lebih bagus dari film Laskar Pelangi.

Kajian tehnis olah digital dilihat dari aspek fotografis poster film Sang pemimpi yang fenomenal dari tetralogi novel Laskar Pelangi sangat menarik untuk diangkat menjadi topik kajian. Sehingga kita akan tahu korelasi antara konten dengan kwalitas yang bagus dengan media pendukung komunikasi visual yang justru menjadi ujung tombak untuk merayu audien menonton film tersebut. Di sisi lain kita memiliki dasar acuan untuk memetakan penyebaran pelaku instan dalam seni visual digital yang diserap pasar komersial kelas atas.

\section{METODE}

Metode yang dipakai dalam penulisan ini adalah kajian tehnis yang meliputi tahapan proses produksi dan elemen visual diseputar olah digital dengan prespektif aspek fotografis. 


\section{PEMBAHASAN}

Materi pembahasan hanya menyoroti analisa tehnis olah digital poster film sang pemimpi yang tidak sesuai dengan aspek fotografis saja. Data visual pembanding akan kita hadirkan untuk membantu kejelasan analisa tehnis. Elemen-elemen desain, komposisi bahkan dampak komunikasi visual secara psikologis kita kesampingkan untuk menghindari hambatan penajaman pokok bahasan. Pembahasan hanya berpijak pada teori tehnis olah digital yang berhubungan dengan aspek fotografis.

Untuk menghindari terjadinya bias pemahaman istilah dan ruang lingkup bahasan, perlu adanya persamaan visi tentang masalah tersebut diatas. Cara yang paling efektif adalah dengan sedikit penjabaran istilah yang berkenaan dengan pokok bahasan seputar pemaknaan proses olah digital dan korelasinya dengan aspek-aspek yang berhubungan dengan fotografi.

\section{Olah Digital (Digital Imaging)}

Seiring dengan perkembangan tehnologi, Olah Digital menjadi cabang seni baru bagian penting dari Fotografi Digital. Dalam pengertian yang sangat sederhana Olah Digital diartikan sebagai proses pengolahan gambar melalui perangkat komputer. Olah digital sendiri dikelompokkan berdasarkan tujuan pengolahan gambar seperti:

\section{Photo Retouching}

Proses pengolahan gambar dengan menggunakan perangkat komputer yang hanya bertujuan untuk memperbaiki kwalitas gambar dari sisi tingkat kekontrasan, saturasi warna, ketajaman dan croping gambar. Kemampuan pengolahan digital semacam ini sebenarnya dapat dilakukan didalam pengaturan kamera. Dengan begitu sebenarnya pengolahan gambar sudah kita lakukan sebelum terjadinya proses pengambilan gambar.

\section{Photo Manipulation}

Proses pengolahan gambar dengan menggunakan perangkat komputer yang tidak hanya bertujuan untuk memperbaiki kwalitas gambar tetapi lebih kepada penggabungan beberapa bagian gambar untuk mendapatkan tampilan visual baru yang berupa realitas fiktif bahkan super fantasi yang tidak terbayangkan sebelumnya. Proses ini bisa berasal dari penggabungan antar foto atau penggabungan foto dengan object lain yang berasal dari perangkat lunak 3D dan dibumbui efek dari Photoshop. Proses ini kadang membutuhkan sentuhan Digital painting dalam pengerjaannya. Manipulasi foto memiliki tingkat kerumitan yang sangat tinggi antara proses pengerjaan dan kemampuan penguasaan berbagai macam perangkat lunak yang menunjang kebutuhan itu. Perangkat lunak yang paling umum digunakan secara profesional untuk kebutuhan ini adalah Adobe Photoshop.

\section{Aspek Fotografis}

Istilah aspek fotografis merujuk pada pengertian sesuatu yang berhubungan dengan kaidahkaidah fotografi secara tehnis. Kaidah fotografi itu sendiri didalamnya mengandung logika cahaya, optis dan atmosfer untuk membentuk kedalaman obyek baik tunggal maupun jamak. Uraian singkat dari masing-masing kandungan kaidah fotografi itu adalah: (1) logika cahaya, parameter untuk 
menentukan arah datangnya cahaya dari sumber cahaya utama, pendukung atau dari pantulan obyek disekitar obyek penerima cahaya; (2) logika optis, meliputi ketajaman dan distorsi obyek karena perbedaan jarak yang menghasil kan dimensi keruangan. asumsi penggunaan lensa dengan focal length yang telah ditentukan dari proses awal penggabungan antar obyek, sangat mempengaruhi proses selanjutnya; (3) logika atmosfer, media interaksi antar obyek dengan nilai keruangan yang luas, berupa efek kabut, uap air, debu, refleksi warna dan flare dengan parameter kondisi cuaca dan lokasi. efek dari logika ini akan menghasilkan dramatisasi mood dan kesan natural pada gambar.

Proses penggarapan karya olah digital melalui beberapa tahap, dari proses penggambilan gambar sampai final touch hingga menjadi final artwork karya olah digital adalah:

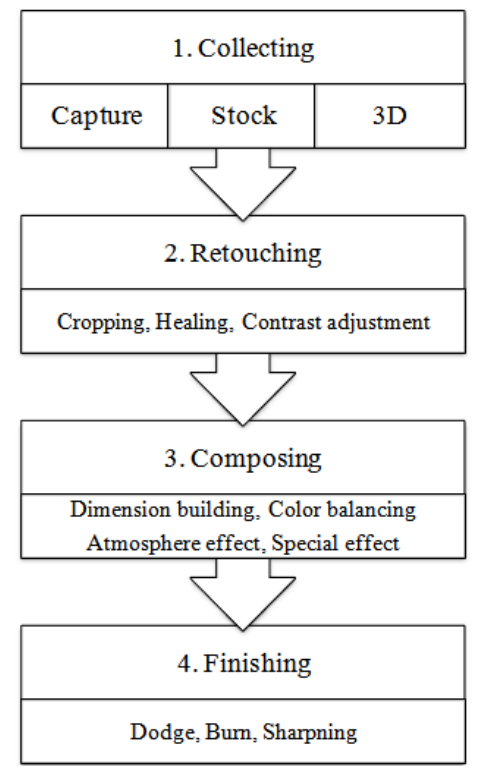

Gambar 1 Skema proses tahapan manipulasi foto

Berdasarkan urutan proses diatas dibutuhkan pemahaman aspek-aspek fotografis disetiap tahapannya. Proses semacam ini biasa dipergunakan untuk kebutuhan manipulasi foto secara komprehensif. Composing adalah proses yang mempunyai peranan penting dalam memanipulasi foto, karena dari proses ini realistic view dapat terbentuk dengan sempurna. Tingkat kegagalan tertinggi dari olah digital untuk memanipulasi gambar adalah, ketika proses composing hanya mengandalkan kemampuan tehnik semata tanpa mengindahkan Aspek fotografis.

\section{Data Visual}

Poster film Sang Pemimpi menggunakan Illustrasi foto. Illustrasi atau gambar yang ditampilkan adalah hasil dari rekayasa digital yang tersusun dari beberapa obyek foto dengan pengambilan gambarnya terpisah. Pendekatan eksekusi poster film tersebut adalah realistic photo dengan tehnik olah digital foto manipulasi. Karakteristik pencahayaan pada obyek utama adalah hard light dengan menggunakan 3 sumber cahaya diantaranya; Front light dan dua edge light. Pendekatan warna yang digunakan standard dengan kontras tinggi. 


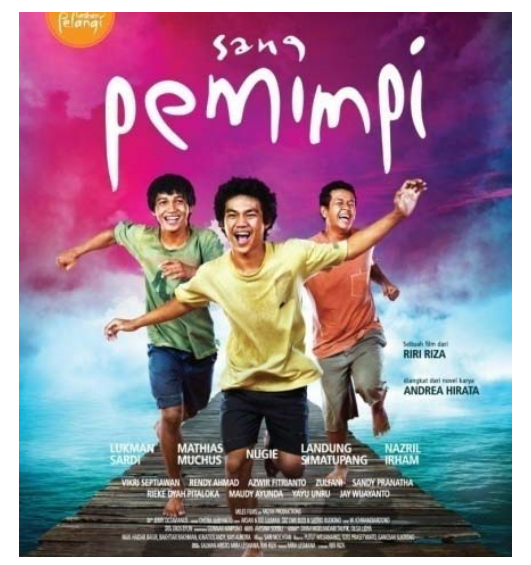

Gambar 1 Poster film Sang pemimpi

Data visual dalam bentuk gambar poster film ini yang akan menjadi acuan secara rinci untuk kita bedah secara tehnis berdasarkan kasus olah digital yang terjadi. Kekuatan konten komunikasi yang melekat dalam poster film Sang pemimpi ini kita kesampingkan sebagai data kajian yang nantinya menjadi landasan pijak analisa kajian. Data visual pembanding akan kita hadirkan sebagai referensi visual, meskipun obyek kajian utamalebih menitik beratkan kepada kajian tunggal yang hanya menyoroti obyek kajian sebagai materi visual yang independen tanpa keterikatan dengan obyek kajian lain, data visual pembanding akan memberikan gambaran kepada kita kekuatan dan kelemahan karya olah digital yang ada. Data visual pembanding ini kita hadirkan secara subyektif, dengan kata lain tidak merefleksikan kekuatan komunitas tertentu.

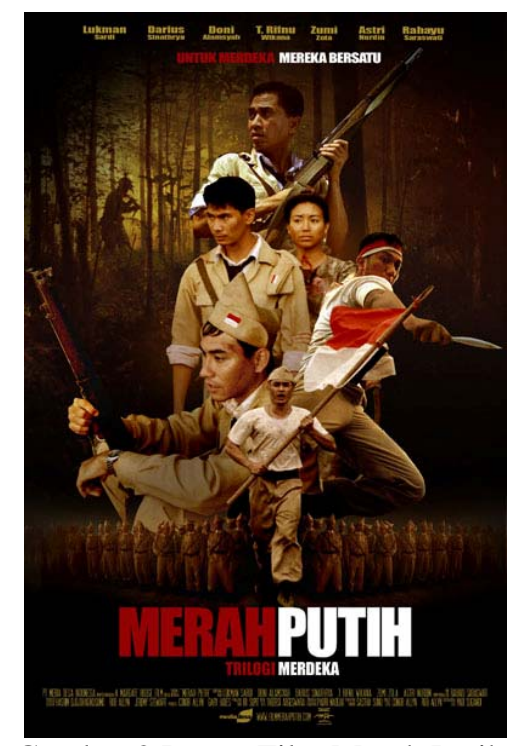

Gambar 2 Poster Film Merah Putih

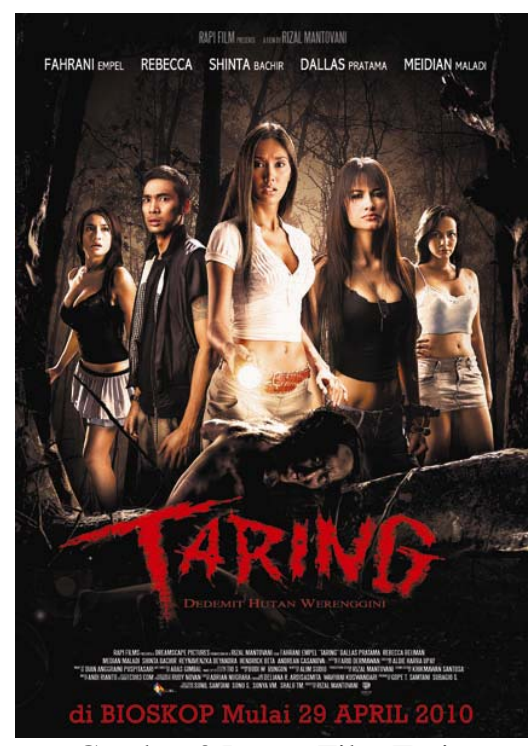

Gambar 3 Poster Film Taring 


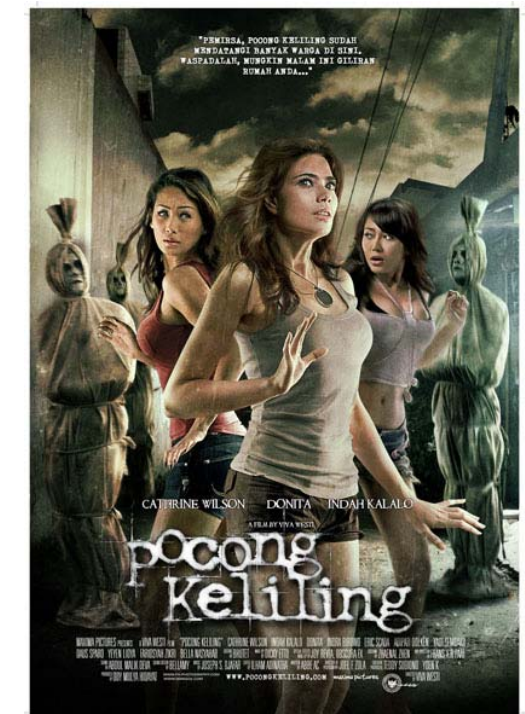

Gambar 4 Poster Film Pocong Keliling

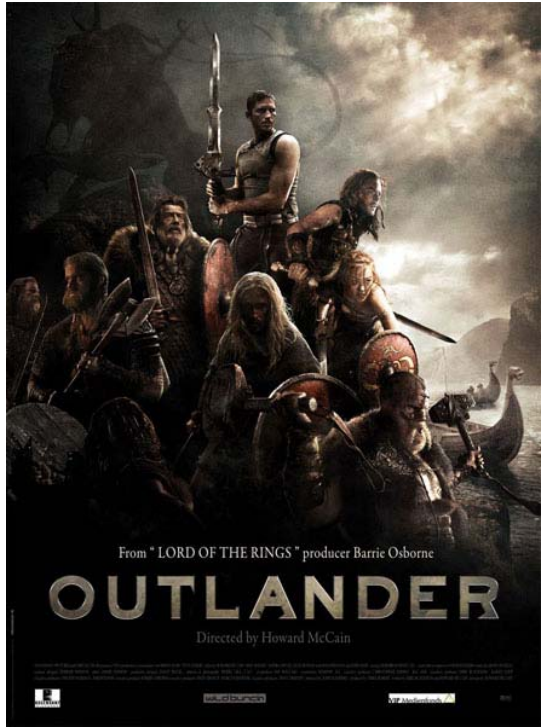

Gambar 5 Poster Film Outlander

\section{Analisa Visual dari Aspek Fotografis}

Untuk memudahkan kajian kita akan coba menguraikan data visual yang ada dengan layout dalam bentuk blok warna. Dengan begitu kita dapat mengidentifikasikan antar obyek atau bagian gambar yang ada dengan lebih mudah.

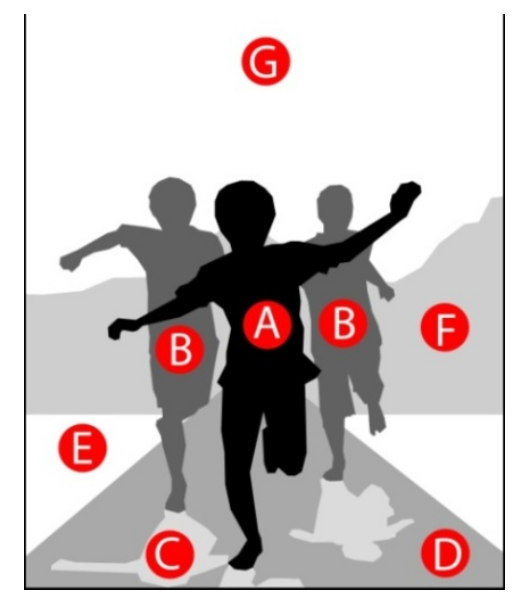

Gambar 6 Layout pemisahan obyek;

A. Obyek utama, B. Obyek utama kedua, C. Bayangan, D. Geladak, E. Air laut, F. Kabut, G. Langit

Gambar 6 di atas menerangkan perbedaan obyek yang dipisahkan dengan blok warna yang berbeda. Dengan demikian kita bisa menganalisa dengan cermat hubungan antara obyek yang satu dengan obyek yang lain dalam proses composing. Hubungan antar obyek akan diperinci dengan gambar yang ada di bawah ini berdasarkan jarak. Karena dengan mengetahui jarak dari masing-masing obyek kita dapat mengkaji depth of field gambar tersebut. 


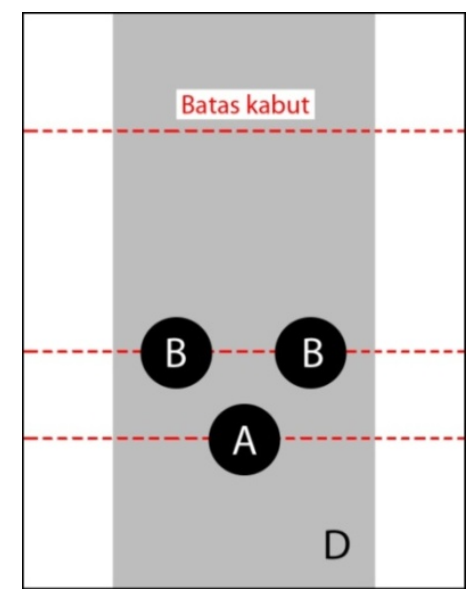

Gambar 7 Tampak atas Layout Jarak antar Obyek

Kalau kita cermati lebih detail, kita bisa melihat adanya dualisme dalam penggunaan ruang tajam atau Depth of field gambar tersebut. Ujung gambar D melewati pada batas kabut, dengan kata lain obyek tersebut jauh dari obyek utama yang berfungsi sebagai titik focus utama. Pada jarak tersebut kita tidak mungkin menggunakan Diafrahma yang sangat kecil mengingat situasi yang ada, berkabut. Sehingga pasokan cahaya kurang maksimal. Dari sini bisa kita simpulkan korelasi antara jarak dengan ketajaman sangat rentan sekali. Obyek-obyek yang jauh dari titik focus ber angsurangsur menjadi blur. Kalau kita lihat materi gambar pada Poster fim Sang Pemimpi terjadi sebaliknya. Lebih jelasnya lagi kita lihat cuplikan gambar pada poster tersebut.

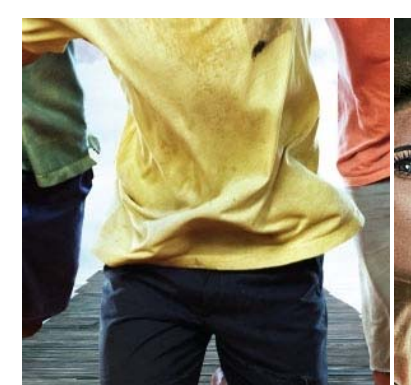

Gambar 8a

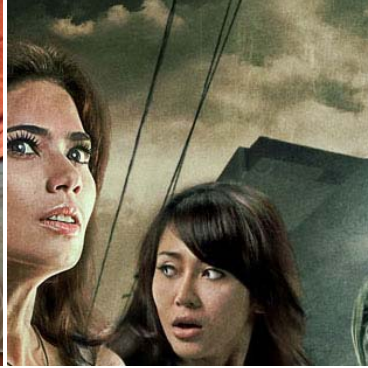

Gambar 8b

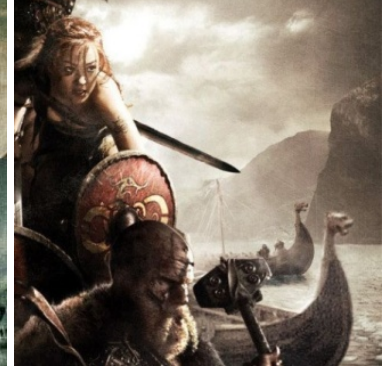

Gambar 8c

Gambar 8a adalah cupilkan dari Gambar 1, ketajaman pada garis gladak masih sangat maksimal akibat dari tehnik croping dan composing yang kurang bagus. Kasus tersebut terjadi juga pada data pembanding Gambar 8b cuplikan Gambar 3, garis pada atap rumah terlalu tegas. Lain halnya dengan data pembanding Gambar 8c cuplikan Gambar 4, kita bisa melihat dimensi yang diakibatkan oleh jarak terjaga sangat rapi, ketajaman antar obyek bervariasi dipisahkan oleh jarak.

Teknik croping bentuk yang digunakan dalam Poster Sang Pemimpi tidak disesuaikan dengan ketegasan garis yang berada pada obyek tersebut, seperti serat-serat kayu geladak yang sejajar dengan area croping. Penggunaan feather yang dinamis melalui jalan multi masking sangat diperlukan untuk menghindari kejanggalan visual. Dalam realitasnya sumber cahaya alam adalah satu, diiringi dengan sumber cahaya pendukung yang jumlahnya bisa lebig dari satu. Sumber cahaya utama inilah yang menghasilkan bayangan untuk semua obyek yang berada dalam jangkauan frame gambar tersebut. Bayangan yang di hasilkan mempunyai derajat yang sama dalam arah jatuhnya.

Poster film Sang Pemimpi mempunyai kasus jatuhnya bayangan cukup serius, karena berada pada obyek utama dan pendukung. Sumber cahaya utama berasal dari sudut 0 derajat dari atas turun 
10 derajat, melihat arah cahaya utama seperti hitungan tadi, harusnya bayangan agak jatuh kebelakang. Yang terjadi pada poster film Sang Pemimpi bayangan jatuh kedepan, karena mengikuti sumber cahaya dari belakang. Sementara kalau menganggap sumber cahaya utama dari belakang maka jatuhnya cahaya yang menyinari obyek utama akan janggal. Ada dua persepsi sumber cahaya utama yang diterapkan di obyek utama dan pendukung. Terjadi kerancuan logika cahaya dalam aspek fotografis. Untuk lebih jelasnya Gambar 9 di bawah menampilkan gambar layout yang menerangkan dari arah mana cahaya itu berasal.

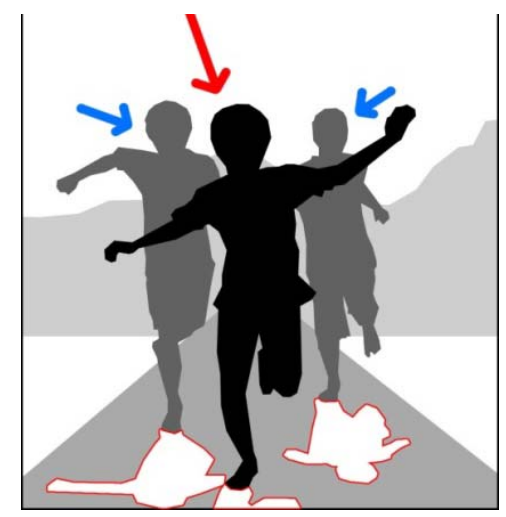

Gambar 9 Layout arah cahaya

Bagian akhir dari analisa ini lebih menyoroti ketidak selarasan dalam membangun atmosfer dari sisi keseimbangan warna antara obyek dengan obyek lain yang lebih dominan. Pengaruh refleksi warna dari latar belakang seharusnya mempengaruhi obyek yang lebih kecil didalamnya. Pada obyek air laut yang ukurannya lebih kecil tidak menghadirkan kandungan warna dominan yaitu kuning kemerahan. Logika atmosfer yang terjadi tidak bisa diterima secara Aspek fotografis.

\section{PENUTUP}

Kemampuan untuk menghadirkan karya seni visual digital yang berbasis olah digital manipulasi foto harus diimbangi dengan kemampuan memahami aspek-aspek fotografis secara detail. Aspek fotografis itu menyangkut logika yang ada didalam tehnik fotografi itusendiri. Logika-logika tersebut tidak bisa kita abaikan kalau kita menginginkan karya tersebut mempunyai bobot visual dari segi tehnis, seperti logika Cahaya, Optis dan Atmosfer. Poster Film "Sang Pemimpi" ternyata mempunyai banyak sekali kelemahan visual dari Aspek fotografis. Meskipun kalau kita lihat selewat suguhan visual tersebut sempurna tanpa cacat. Ternyata kebesaran film tersebut tidak bisa jadi tolak ukur terhadap kwalitas materi komunikasi visual turunannya.

\section{DAFTAR PUSTAKA}

Peres, M. R. (2008). The concise focal encyclopedia of photography. UK: Focal Press.

Rand, G. D. R. (2008). Zone system photography. New York: Amherst Media.

Reeder, R. (2007). Digital negatives. UK: Focal Press.

Sarvas, R. (2011). Fron snapshot to social media-the changing picture of domestic photography. UK: Springer. 